\title{
Melon fruit quality front mildew incidence and management of nitrogen and potassium topdressing
}

\author{
Gil Rodrigues Santos'*, Aurenivia Bonifacio', Artenisa Cerqueira Rodrigues², \\ Mateus Sunti Dalcin', Renato Almeida Sarmento', Ildon Rodrigues Nascimento'
}

'Universidade Federal do Tocantins, Gurupi, Brasil.
'Universidade Federal do Piauí, Teresina, Brasil.
*Corresponding author e-mail:gilrsan@uft.edu.br

\begin{abstract}
This work aimed to evaluate the application effect of different dosages of nitrogen and potassium topdressing on mildew severity and on yield and fruit quality of melon. The three cultivars, Jangada, Gaucho Casca de Carvalho and Gaucho Redondo Cone Sul were evaluated in Cerrado (savannah) and floodplain areas. At 34 days after sowing (DAS) the topdressing treatments with different dosages of nitrogen and potassium were applied. The mildew severity estimation started at 56 DAS and was performed in five-days intervals until the harvesting of the fruits. The yield and physicochemical characteristics of the collected fruits were evaluated at harvest. There was no significative interaction among nitrogen and potassium topdressing, the cultivars and cultivated areas. However, there was significative differences when the factors were analyzed in separate. The cultivar Gaucho Redondo Cone Sul showed a significant linear increase in the area under the disease progress curve and higher productivity on cerrado compared to the remaining cultivars. The cultivar Gaucho Casca de Carvalho produced heavier and with higher B Brix fruits on cerrado. It is possible to conclude that the applied topdressings did not reduce the mildew severity in all tested cultivars, but they increased the yield in the floodplain area without modifying the physicochemical characteristics of the pulp on the evaluated melon fruits.
\end{abstract}

Keywords: Pseudoperonospora cubensis; melon; fertilizers; postharvest

\section{Introduction}

The melon is very appreciated and has a great popularity in the world, standing out for being one of the most exported fresh fruits by Brazil (SEAGRO, 2012). Among the Brazilian states, Tocantins presents ideal conditions for melon plant cultivation (Cucumis melo L.), with elevated temperatures and low air relative humidity (Santos et al., 2009). More than favoring the crop growth, these conditions minimize the incidence of diseases and proportionate a better fruit quality (Demiral \& Koseoglu, 2005; Chakraborty \& Newton, 2011). Among the diseases which attack the melon plant, stand out fusarium wilt (Fusarium oxysporum f. sp. melonis Snyd. et Hans.), gummy stem blight (Didymella bryoniae (Aversw.)

Rehm), powdery mildew (Sphaerotheca fuliginea (Schlecht.: Fr.) Pollacci) and mildew (Pseudoperonospora cubensis Berkeley \& Curtis) (Santos et al., 2009; Savory et al., 2010; Zhao et al., 2011; Lebeda \& Cohen, 2011 ; Santos et al., 2013). Mildew occurs in different environments, covering, therefore, since the semiarid until the tropical environment. It is more problematic in the wet periods with mild temperatures, when it might cause severe losses (Lebeda \& Cohen, 2011; Cohen et al., 2014). Being a pathogen that presents a great aggressivity in conditions of elevated humidity, it occasions the reduction in the foliar area and, therefore, a reduction of 
photosynthesis, implyingindamagesto production and elevated losses in the crop (Medeiros et al., 2007; Savory et al., 2010; Santos et al., 2013). The dissemination of $P$. cubensis occurs through the wind, rain drops or irrigation through aspersion (Lebeda \& Cohen, 2011). For the mildew control the usage of fungicides or adequate agricultural practices is recommended, reducing the period of foliar wetting (Santos et al., 2013; Cohen et al., 2014).

Beyond the excess of soil humidity, the fertilization might affect the defense reaction of the melon to pathogens, influencing the progress of diseases, either bacterial or fungal (Santos et al., 2009; Pautasso et al., 2012). Potassium exercises an important function in the translocation of carbohydrates during fruit production (Chakraborty \& Newton, 2011) and it mainly influences the quality of these fruits, (Demiral \& Koseoglu, 2005; Malavolta, 2005; Medeiros et al., 2007; Viana et al., 2007; Zhang et al., 2010) which might increase the tolerance to pathogen attacks (Datnoff et al., 2007; Chakraborty \& Newton, 2011).

Pereira et al. (2012) recommend the application of potassium phosphite as an efficient alternative for mildew control in Merlot grapes, whose response is similar to that proportionated by fungicides. Gonçalves et al. (2004) did not find correlation between nitrogen increment in mildew incidence ( $P$. cubensis) in onion. As to melon, an inversely proportional relation

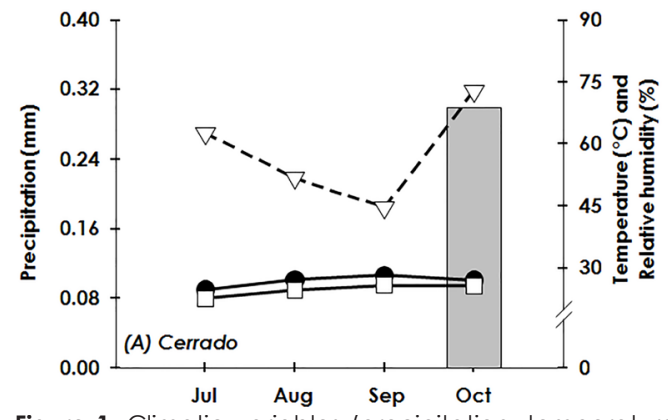

Figure 1. Climatic variables (precipitation, temperature and relative humidity) obtained during the experimental period (July to October, 2011) on Cerrado (A) and floodplain (B) areas.

Soil preparation was performed according to the adopted for the conventional system. The planting fertilization was performed based on soil analysis (Table 1) and followed the recommended dosages on the available literature for melon crop (Moreira et al., 2009). Seven days after the planting fertilization, the between mildew severity and the concentration of total soluble solids in the fruits was registered. The concentration of total soluble solids is one of the most important variables in the measuring of melon fruit quality (Medeiros et al., 2007; Queiroga et al., 2008; Silva et al., 2008; Santos et al., 2009, 2013).

With the exposed, this work aimed to evaluate the application effects of different dosages of nitrogen and potassium topdressing in mildew severity and also in the yield and fruit quality of melon cultivars.

\section{Material and methods}

The experiments were conducted in a Cerrado area, situated on the coordinates $11^{\circ} 43^{\prime} 45^{\prime \prime} \mathrm{S}$ and $49^{\circ} 04^{\prime} 07^{\prime \prime} \mathrm{W}$ at an average height of $280 \mathrm{~m}$, and another of floodplain, situated on the coordinates $11^{\circ} 45^{\prime} 34^{\prime \prime} \mathrm{S}$ and $49^{\circ} 40^{\prime} 07^{\prime \prime}$ W at an average height of $189 \mathrm{~m}$. The experiments were simultaneously conducted within the period from June to October of 2011 , the dryer period, with low air relative humidity (Figure 1). The Cerrado climatic data were provided by the Meteorological Station of the University Campus of Gurupi, Federal University of Tocantins (Gurupi, TO), while the floodplain area data were provided by Meteorological Station of the National Institute of Meteorology (INMET), located on the Rio Formoso Project (Formoso do Araguaia, TO).

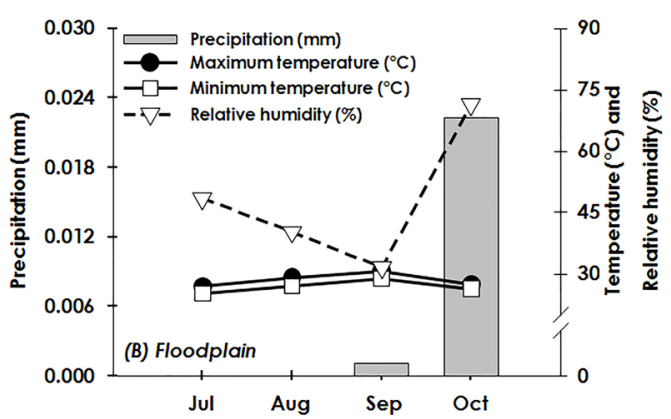

sowing was performed with the deposit of four seeds in 5,0 cm deep grooves posteriorly covered with $2,0 \mathrm{~cm}$ of soil. The following cultivars of yellow melon were evaluated: Jangada, Gaúcho Casca de Carvalho and Gaúcho Redondo Cone Sul. Twenty days after sowing (DAS) the thinning was performed, allowing two plants per groove. 
Table 1. Soil analysis in the experimental areas of Cerrado and floodplain.

\begin{tabular}{|c|c|c|c|c|c|c|c|c|}
\hline Areas & $\begin{array}{c}\mathrm{pH} \\
\left(\mathrm{H}_{2} \mathrm{O}\right)\end{array}$ & $\begin{array}{r}\text { Phosphc } \\
\text { (r }\end{array}$ & $\begin{array}{l}\text { Potassium } \\
\left.n^{-3}\right)\end{array}$ & Calcium & $\begin{array}{r}\text { Magnesium } \\
\quad \text { (cmol }_{\mathrm{c}} \mathrm{d}\end{array}$ & $\begin{array}{l}\text { Aluminium } \\
\left(\mathrm{m}^{-3}\right)\end{array}$ & $\mathrm{H}+\mathrm{Al}$ & $\begin{array}{l}O M \\
(\%)\end{array}$ \\
\hline Cerrado & $\overline{5.7}$ & 3.7 & 27.1 & 1.7 & 0.5 & 0.08 & 2.9 & 69.5 \\
\hline Floodplain & 5.3 & 6.4 & 19.0 & 3.3 & 1.2 & - & 3.4 & 68.5 \\
\hline
\end{tabular}

The differentiation of treatments occurred at 34 DAS, when different topdressing levels(treatments) were applied, resultant from the combination of three nitrogen dosages 160,90 and $120 \mathrm{~kg} \mathrm{ha}^{-1}$ ) and three dosages of potassium (150, 200 and $250 \mathrm{~kg} \mathrm{ha}^{-1}$ ), as follows: $60 \mathrm{~kg} \mathrm{ha}^{-1}$ of $\mathrm{N}$ and $150 \mathrm{~kg} \mathrm{ha-1}$ of $\mathrm{K} ; 90 \mathrm{~kg} \mathrm{ha}^{-1}$ of $\mathrm{N}$ and $200 \mathrm{~kg} \mathrm{ha}^{-1}$ of $\mathrm{K}$; and $120 \mathrm{~kg} \mathrm{ha}^{-1}$ of $\mathrm{N}$ and $250 \mathrm{~kg}$ $\mathrm{ha}^{-1}$ of $\mathrm{K}$. The topdressing epoch and the nitrogen and potassium dosages utilized in the treatments were chosen based on the recommendations for the crop (Moreira et al., 2009). The urea and the potassium chlorate were the respective sources of nitrogen and potassium.

The experimental design was in randomized blocks with a factorial scheme of $2 \times 3 \times 3$, with two experimental areas; three levels of nitrogen and potassium topdressing and three melon cultivars, with four repetitions. The experimental parcel was composed by three lines of 2,0 m length, with a 0,50 $\mathrm{m}$ spacing between lines and 0,2 $\mathrm{m}$ between plants. Only the central line was considered as a useful parcel for the evaluations. In each line 10 groves were opened and four melon seeds were inserted in each groove. Seven days after sowing the thinning was performed, allowing 10 plants per linear meter. The weeds were controlled through manual hoeing and the branches were directed to the interior of the parcel.

As to irrigation, the conventional aspersion system was utilized in the essay stablished on Cerrado, and groundwater utilization (flooding) in the experiment with floodplain conditions. The insecticide Thiametoxam (250 g of commercial product ha-1) was utilized for the cucurbit beetle infestation control (Diabrotica spp.) on Cerrado, while the insecticides Imidacloprid (200 $\mathrm{g}$ of commercial product ha-1), Metamidofós (600 $\mathrm{g}$ of commercial product ha-1), Spiromesifen (400

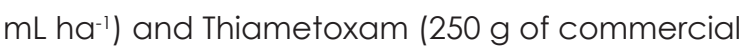
product ha-1) were applied in the floodplain area for the control of thrips (Thrips tabaci), greenfly
(Aphis gossypii), caterpillars (Diaphania spp.), silverleaf whitefly (Bemisia tabaci) and cucurbit beetle.

The mildew severity estimative on the leaves begun at 56 DAS and was performed in intervals of five days until harvest. For this, the note scale proposed by Santos et al. (2009) was utilized, where: 0 - healthy plant; 1 - less than $1 \%$ of injured foliar area; 3 - within 1 and $5 \%$ of injured foliar area; 5 - within 6 and $25 \%$ of injured foliar area; 7 - within $26-50 \%$ of injured foliar area; 9 - more than $50 \%$ of injured foliar area. The data obtained through scale were utilized for the calculation of the area under the disease progress curve (AUDPC) according to Shaner \& Finney (1977).

The experiment was concluded at 77 DAS, when the fruits of the useful area of the parcel were collected and weighed for the quantifying of the yield $\left(t \mathrm{ha}^{-1}\right)$. As to the physicochemical properties of the yellow melon fruits, the total soluble solids were quantified, along with the total titratable acidity (\% of citric acid) according the standard methodology (IAL, 2008).

The results were subjected to variance analysis in a factorial scheme ( $F$ test, $P<0,05)$. When the $F$ test was significative, Tukey's test was applied $(P<0,05)$ for the genotypes and the regression analysis to evaluate the effect of the different dosages of the nitrogen and potassium fertilizations. The statistical analyses were performed utilizing the statistical software ASSISTAT.

\section{Results and discussion}

All evaluated melon cultivars were susceptible to mildew, with the appearing of the first symptoms at 56 DAS, on Cerrado and floodplain areas, similarly to the results reported by Santos et al. (2009) when they evaluated the reaction of 28 genotypes of melon to mildew in field conditions. Based on the mildew severity data on melon plant, of the area under the 
disease progress curve (AUDPC) was calculated and, after statistical analysis, it was confirmed that there was no significative interaction among fertilization, the cultivars and the areas of study for this variable. The cultivar Gaúcho Redondo Cone Sul presented a significative linear increase of AUDPC when cultivated on Cerrado in response to the nitrogen and potassium fertilization, while for the other cultivars there was no significative difference (Figure 2A).

The AUDPC indicates the speed in which the disease manifests throughout time, and high values of this parameter reflect a greater speed of the disease progress (Simko \& Piepho, 2012). The AUDPC value in the plants of melon cultivar

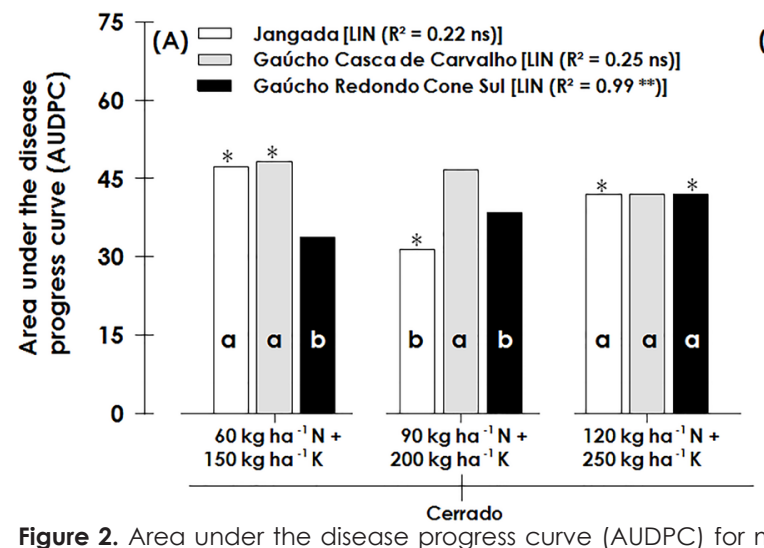

Gaúcho Redondo Cone Sul was increased in $25 \%$ when comparing topdressing with $60 \mathrm{~kg} \mathrm{ha}^{-1}$ of nitrogen and $150 \mathrm{~kg} \mathrm{ha}$ of potassium in relation to the topdressing with $120 \mathrm{~kg} \mathrm{ha}^{-1}$ of nitrogen and $250 \mathrm{~kg} \mathrm{ha}^{-1}$ of potassium in Cerrado conditions (Figure 2A). On the floodplain, the cultivar Gaúcho Casca de Carvalho stood out, presenting a significative linear increase in AUDPC in response to the nitrogen and potassium topdressing, especially when were utilized $60 \mathrm{~kg} \mathrm{ha}^{-1}$ of nitrogen and $150 \mathrm{~kg} \mathrm{ha}^{-1}$ of potassium. This dosage induced an increase of $20 \%$ in AUDPC compared to the topdressing with $120 \mathrm{~kg} \mathrm{ha}^{-1}$ of nitrogen and $250 \mathrm{~kg} \mathrm{ha}^{-1}$ of potassium (Figure 2B).

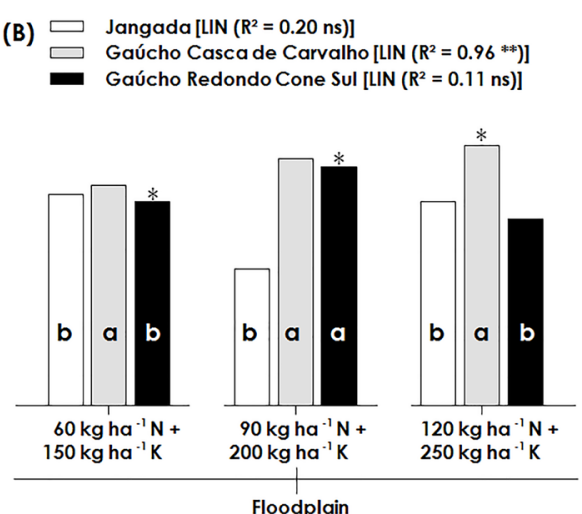

$\square$ Gaúcho Casca de Carvalho [LIN $\left.\left(R^{2}=0.96^{* *}\right)\right]$

Floodplain cultivars Jangada, Gaúcho Casca de Carvalho and Gaúcho Redondo Cone Sul subjected to different dosages of nitrogen and potassium topdressing. Cultivars averages followed by the same letter do not differ among each other in each dosage, while the asterisk $\left({ }^{*}\right)$ indicates the highest average of each cultivar on the two areas (Tukey's test; $\mathrm{p}<0,05) .{ }^{* *}-\mathrm{R}^{2}$ significative at $5 \%, \mathrm{~ns}-\mathrm{R}^{2}$ not significative.

Santos et al. (2013), studying the effect of humidity (Santos et al., 2011). The lack of resistant different nitrogen dosages in formulation with the potassium (NPK 20-00-20) applied in topdressing in the severity of the gummy stem blight (Didymella bryoniae) in watermelon, verified that the fertilization with these nutrients did not affect the severity of the disease. Disease severity might be influenced by the handling quality of the crops and by the climate, together favoring or not the relation between the vegetal species and the pathogen (Araújo et al., 2010; Lebeda \& Cohen, 2011 ; Pautasso et al., 2012). Furthermore, other factors such as the plant age and the nutritional status might actuate determining a higher or lower susceptibility to diseases (Chakraborty \& Newton, 2011). In general, the adopted measures for the disease control are based on the usage of fungicides, although the efficacy of these substances might be reduced in very susceptible cultivars or in planting areas with excess of cultivars to the most common diseases in melon is considered a limiting factor for the expansion of cultivation areas and contributes to a low yield (Santos et al., 2009, 2011).

In the yield evaluation (Figure 3 ) of the tested melon cultivars in the two areas there were found no significative interactions among the applied treatments. The cultivar Gaúcho Redondo ConeSul presented a higherproductivity compared to the remaining evaluated cultivars, independently of the nitrogen and potassium dosages applied in topdressing. The variability in the yield of a determined crop in the field might be inherent to the soil, to the climate, or induced by the handling (Medeiros et al., 2007; Viana et al., 2007; Silva et al., 2008; Araújo et al., 2010). Viana et al. (2007) report that the fertigated and cultivated melon yield in protected environment was nor responsive to the application of different 
potassium levels.

The correlation between the yield of different yellow melon cultivars and the different environments was significative, considering the higher yield of the floodplain area mainly for the cultivar Gaúcho Redondo Cone Sul (Figure 3B). The yield of cultivar Gaúcho Casca de Carvalho was inferior to the remaining evaluated cultivars. The low yield of the referred cultivar might be related to the climate differences between the two study areas, or to the higher severity of mildew reflected in a higher AUDPC registered for this cultivar in both essays. The reduction in yield might be a consequence of the metabolic alterations induced by $P$. cubensis, since the pathogen, by utilizing the plant reserves for its growth, might actuate as a drain for the nutrients produced by the host plant and, therefore, reduce the availability and the translocation of nutrients for the maturation and development of the fruits (Paiva et al., 2008).

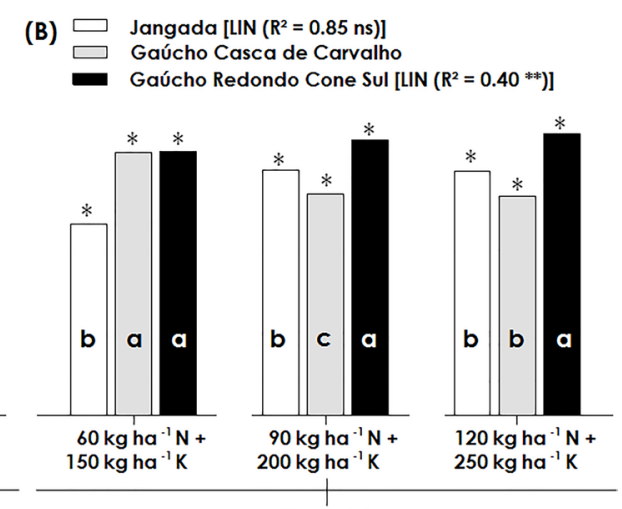

Floodplain

Figure 3. Yield († ha-1) of melon cultivars Jangada, Gaúcho Casca de Carvalho and Gaúcho Redondo Cone Sul subjected to different dosages of nitrogen and potassium topdressing. Cultivars averages followed by the same letter do not differ among each other in each dosage, while the asterisk (*) indicates the highest average of each cultivar on the two areas. (Tukey's test; $\mathrm{p}<0,05) .{ }^{* *}-\mathrm{R}^{2}$ significative at $5 \%$, ns $-\mathrm{R}^{2}$ not significative.

Regarding the weight of the collected fruits, there was no significative interaction $(p<0,05)$ among the dosages of nitrogen and potassium fertilization applied by topdressing, the cultivars and the melon cultivation areas (Figure 4). On Cerrado, the cultivar Gaúcho Casca de Carvalho produced heavier fruits independently of the nitrogen and potassium topdressing (Figure 4A). However, on floodplain, the cultivars Jangada and Gaúcho Redondo Cone Sul stood out with the heaviest fruits. Although the cultivar Gaúcho Redondo Cone Sul produced smaller fruits, in the treatment which received the topdressing with the application of $90 \mathrm{~kg} \mathrm{ha}^{-1}$ of nitrogen and $200 \mathrm{~kg} \mathrm{ha-1}$ of potassium, there was an increment in the fruit weight, possibly explained by the higher yield registered for this cultivar in this topdressing dosage (Figure 3). It is probable that this response is related to a better flow of necessary metabolites for fruit formation (Paiva et al., 2008). Divergent results might yet be explained by the differential response of each cultivar to the specific climatic conditions of each cultivation area, since that on the floodplain a lower air relative humidity was registered during the experiment conduction (Figure 1).

The interaction among the dosages of nitrogen and potassium applied by topdressing, the cultivars and the essay areas for the total soluble solid contents ('Brix) was not statistically significative (Figure 5)). The fruits of cultivar Gaúcho Casca de Carvalho presented a lower linearincrease in ${ }^{\circ}$ Brix when cultivated on Cerrado, while the fruits of cultivar Jangada presented a higher ${ }^{\circ}$ Brix compared to the remaining cultivars (Figure 5A). The ${ }^{\circ}$ Brix reflects the sugars content present in the fruit pulp and might be reduced in response to a higher severity of diseases (Solino et al., 2012). The ${ }^{\circ}$ Brix values on melon fruits stay in a range of $8{ }^{\circ}$ Brix to $10^{\circ}$ Brix, and when the values to not reach this level, the fruits might present reduced size and inferior flavor (Chitarra \& Chitarra, 2005; Paiva et al., 2008). The reduction in ${ }^{\circ}$ Brix with the increase in mildew severity might occur when there is a higher disease pressure (Chitarra \& Chitarra, 2005; Solino et al., 2012).

To attend the identity and quality standards (IQS), the melon pulp must present $\mathrm{pH}$ 

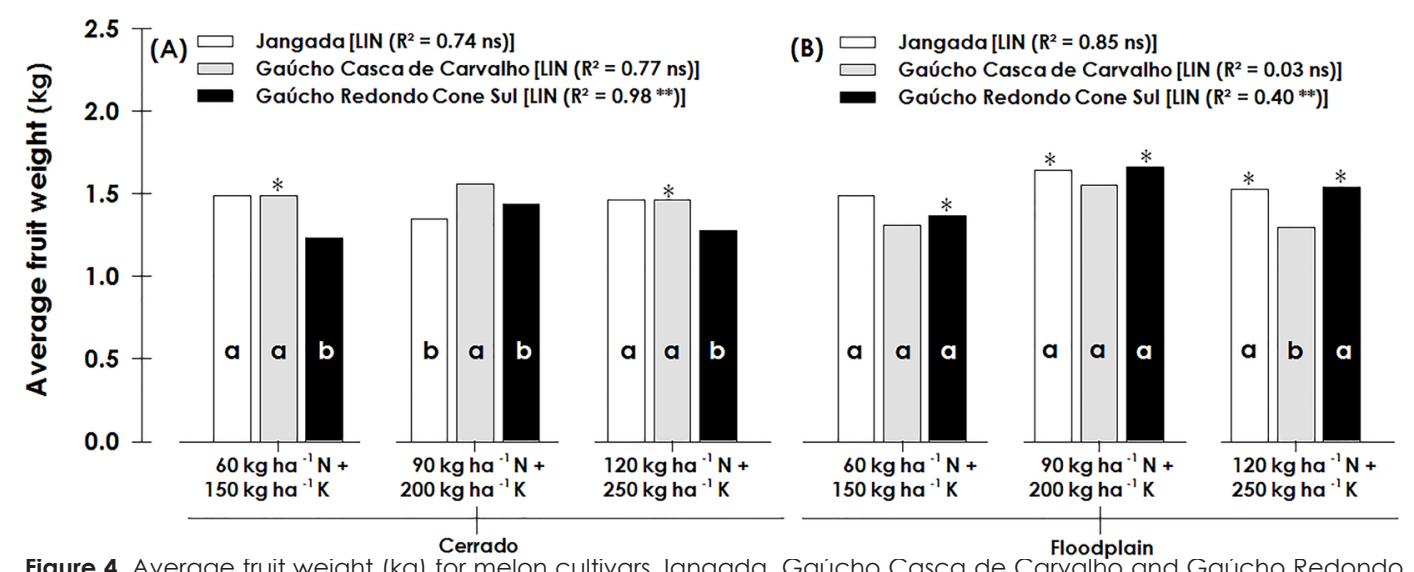

Figure 4. Average fruit weight (kg) for melon cultivars Jangada, Gaúcho Casca de Carvalho and Gaúcho Redondo Cone Sul subjected to different dosages of nitrogen and potassium fertilization applied by topdressing. Cultivars averages followed by the same letter do not differ among each other in each dosage, while the asterisk $(*)$ indicates the highest average of each cultivar on the two areas (Tukey's test; $p<0,05$ ). ${ }^{* *}-R^{2}$ significative at $5 \%$, ns - $R^{2}$ not significative.

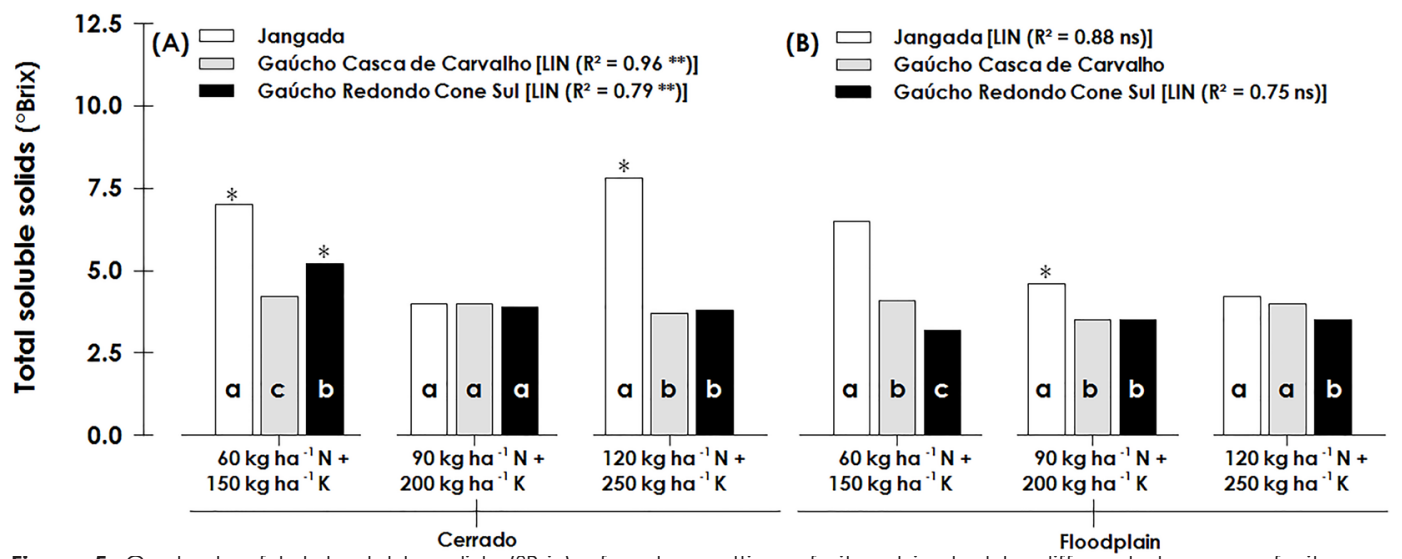

Figure 5. Contents of total soluble solids ('Brix) of melon cultivars fruits subjected to different dosages of nitrogen and potassium topdressing. Cultivars averages followed by the same letter do not differ among each other in each dosage, while the asterisk $(*)$ indicates the highest average of each cultivar on the two areas (Tukey's test; $p<0,05)$.

** - $\mathrm{R}^{2}$ significative at $5 \%$, ns - $\mathrm{R}^{2}$ not significative.

values, ${ }^{\circ}$ Brix and total titratable acidity (TTA) of 4,$5 ; 7,0$ and $0,14 \%$, respectively (BRASIL, 2000)). In this study, the TTA was near the minimal value of the IQS (Figure 6), being near or under 0,10\% on both areas. The fruits of cultivar Gaúcho Casca de Carvalho presented a linear reduction in the TTA with the application of nitrogen and potassium (Figure 6B). The TTA measures the level of organic acids, and alterations in this variable imply in changes in the flavor of fruits (Amorim et al., 2010; Dantas et al., 2010). According to Zhang et al. (2010) and Pautasso et al. (2012), potassium might affect size, acidity and nutritive value of fruits.

The isolated analysis of the TTA and TSS parameters might suggest a false indicative of fruits flavor and, in this manner, the relation between TSS and ATT (ration or TSS/TTA relation) is one of the most practical and precise ways to evaluate fruit flavor and the balance between acids and sugars. (Demiral \& Koseoglu, 2005; Amorim et al., 2010). In this work, the cultivation on Cerrado, generally, proportioned a higher TSS/TTA relation (Figure 7A), however the topdressing dosages did not influence the TSS/ TTA relation. So that the pulps of a specific fruit might be standardized and indicated as of elevated quality, the main evaluated levels are the TSS and TTA and the TSS/TTA relation (Dantas et al., 2010). Santos et al. (2013), on watermelon crop, also did not verify a significative effect of crescent potassium dosages over the TSS/TTA relation.

Elevated values of the TSS/TTA relation indicate that the fruit has reached the maturation stadium and is in the ideal period for harvest (Amorim et al., 2010; Dantas et al., 2010). A higher TSS/TTA relation suggests a better equilibrium between the sweet and the acid, resulting in a more pleasant flavor, making the fruit pulps or the 


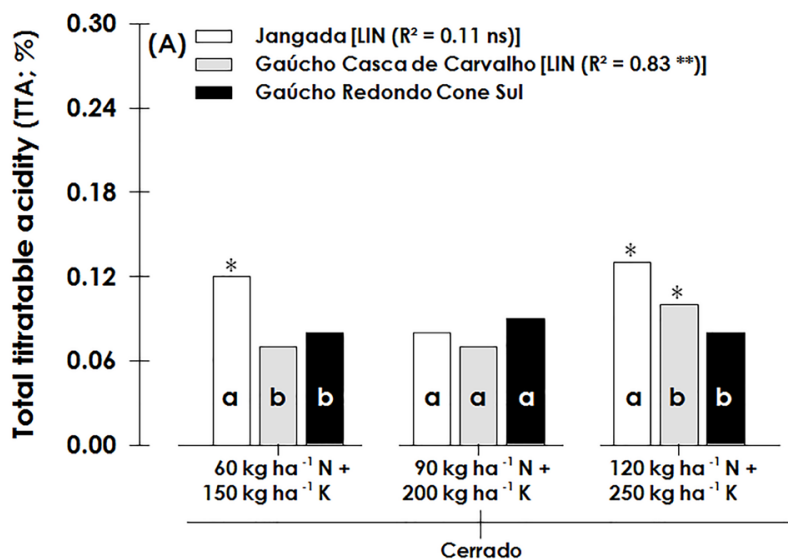
(B) $\square$ Jangada
$\square$ Gaúcho Casca de Carvalho [LIN $\left.\left(R^{2}=0.99 * *\right)\right]$
- Gaúcho Redondo Cone Sul

Figure 6. Total titratable acidity (ATT \%) of melon cultivars fruits subjected to different dosages of nitrogen and potassium topdressing. Cultivars averages followed by the same letter do not differ among each other in each dosage, while the asterisk $\left({ }^{*}\right)$ indicates the highest average of each cultivar on the two areas (Tukey's test; $\left.p<0,05\right) .{ }^{* *}-R^{2}$ significative at $5 \%$, $\mathrm{ns}-\mathrm{R}^{2}$ not significative.

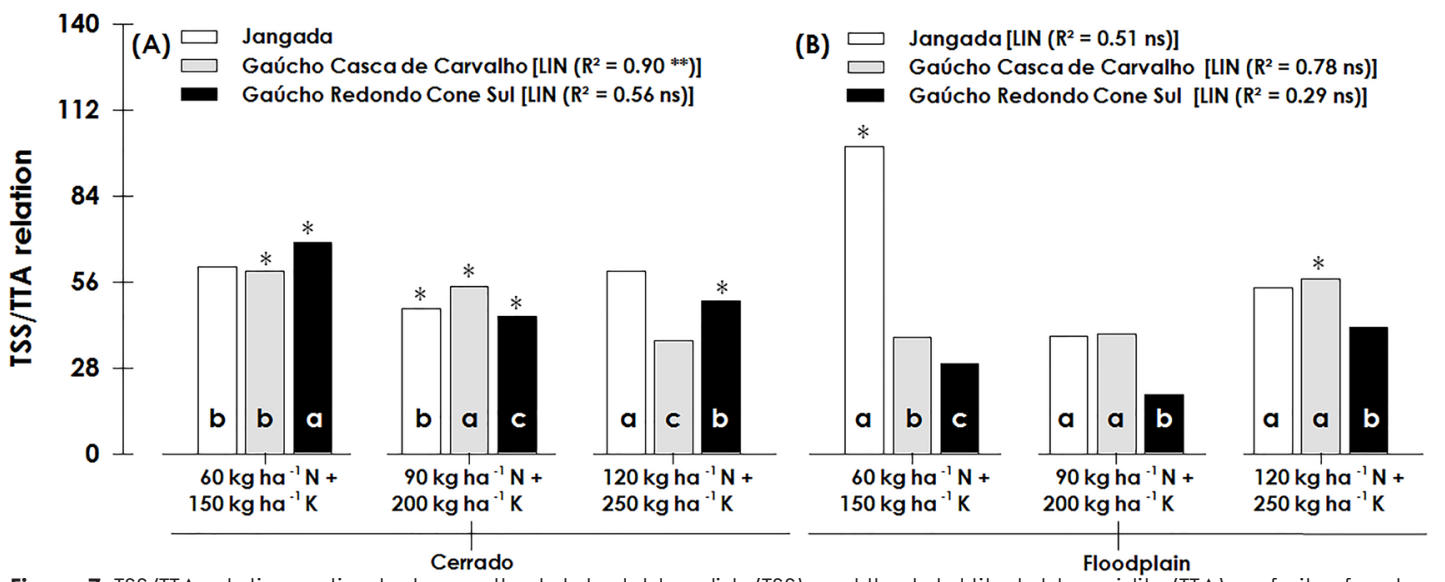

Figure 7. TSS/TTA relation, ration between the total soluble solids (TSS) and the total titratable acidity (TTA) on fruits of melon cultivars subjected to different dosages of nitrogen and potassium topdressing. Cultivars averages followed by the same letter do not differ among each other in each dosage, while the asterisk (*) indicates the highest average of each cultivar on the two areas (Tukey's test; $p<0,05$ ). ${ }^{* *}-R^{2}$ significative at $5 \%, n s-R^{2}$ not significative.

fruit itself more attractive for consumption (Paiva et al., 2008; Amorim et al., 2010). In plants attacked by pathogens, according to Zhang et al. (2010), not palatable fruits might be originated due to a higher storage of organic acids in the pulps in the formation phase, as a result of the reduction or the translocation of photoassimilates.

Santos et al. (2013) report that the fertilization utilizing potassium chloride significantly increases melon yield. However, several authors did no detect efficacy or effect of potassium chloride applied via soil in fruit quality (Demiral \& Koseoglu, 2005; Silva et al., 2008; Queiroga et al., 2008). The values of the TSS/TTA relation must be near to 50 to maintain the IQS of the melon pulp (BRASIL, 2000), since this parameter might be influenced by environmental factors, such as solar light intensity and temperature, and yet by the type and dosages of fertilizers (Dantas et al., 2010).

\section{Conclusions}

There was no significative interaction among the dosages of nitrogen and potassium fertilization applied by topdressing, the cultivars and the melon cultivation areas with the analyzed variables. The applied treatments, however, separately influenced the yield of the evaluated cultivars, which was different on Cerrado and on floodplain.

\section{References}

Amorim, G.M., Santos, T.C., Pacheco, C.V., Tavares, I.M.C., Franco, M. 2010. Avaliação microbiológica, físico-química e sensorial de polpas de frutas comercializadas em ItapetingaBA. Enciclopédia Biosfera 6(11): 1-8.

Araújo, W.F., Oliveira, G.A., Carvalho, F.K., Silva, W.M., Cruz, P.L.S., Maciel, F.C.S. 2010. Manejo da irrigação do meloeiro com base na evaporação do tanque classe A. Horticultura Brasileira 28: 495499. 
BRASIL. Ministério da Agricultura, Pecuária e Abastecimento. 2000. Regulamento técnico geral para fixação dos padrões de identidade e qualidade para suco de fruta (Instrução normativa $n^{\circ}$ 01). Diário Oficial da União, Brasília, Brasil. 15 p.

Chakraborty, S., Newton, A.C. 2011. Climate change, plant diseases and food security: an overview. Plant Pathology 60: 2-14.

Chitarra, M.I.F.; Chitarra, A.B. 2005. Pós-colheita de frutas e hortaliças: fisiologia e manuseio. 2. ed. rev. amp. Lavras: Universidade Federal de Lavras.

Cohen, Y., Rubin, A.E., Galperin, M. 2014. Host preference of mating type in Pseudoperonospora cubensis, the downy mildew causal agent of cucurbits. European Journal of Plant Pathology 139: 641-653.

Dantas, R.L., Rocha, A.P.T., Araújo, A.S., Rodrigues, M.S.A., Maranhão, T.K.L. 2010. Perfil da qualidade de polpas de fruta comercializadas na cidade de Campina Grande-PB. Revista Verde 5: 61-66.

Demiral, M.A., Koseoglu, A.T. 2005. Effect of potassium on yield, fruit quality, and chemical composition of greenhouse-grown galia melon. Journal of Plant Nutrition 28: 93-100.

Gonçalves, P. A. S., Sousa e Silva, C. R., Boff, P. 2004. Incidência do míldio em cebola sob adubação mineral e orgânica. Horticultura Brasileira 22(3): 538-542.

IAL (Instituto Adolfo Lutz). Métodos químicos e físicos para análise de alimentos. São Paulo: Instituto Adolfo Lutz, 2008.

Lebeda, A., Cohen, Y. 2011. Cucurbit downy mildew (Pseudoperonospora cubensis): Biology, ecology, epidemiology, host-pathogen interaction and control. European journal of plant pathology 129(2): 157-192.

Medeiros, J.F., Santos, S.C.L., Câmara, M.T., Negreiros, M.Z. 2007. Produção de melão Cantaloupe influenciado por coberturas do solo, agrotêxtil e lâminas de irrigação. Horticultura Brasileira 25: 538-543.

Moreira, S.R., Melo, A.M.T., Purquerio, L.F.V., Trani, P.E., Narita, N. 2009. Melão (Cucumis melo L.). http://www.infobibos.com/<Acesso em 22 Mar. $2014>$.

Paiva, W.O., Marques, G.V., Mesquita, J.B.R., Dantas, R.S., Freitas, F.W.A. 2008. Qualidade e conservação de frutos de melão Amarelo em dois pontos de colheita. Revista Ciência Agronômica 39: 70-76.

Pautasso, M., Döring, T.F., Garbelotto, M., Pellis,
L., Jeger, M.J. 2012. Impacts of climate change on plant diseases: Opinions and trends. European Journal of Plant Pathology 133(1): 295-313.

Queiroga, R.C.F., Puiatti, M., Fontes, P.C.R., Cecon, P.R. 2008. Produtividade e qualidade de frutos de meloeiro variando número de frutos e de folhas por planta. Horticultura Brasileira 26(2): 209-215.

Santos, G.R., Castro Neto, M., Ramos, L.N., CaféFilho, A.C., Reis, A., Momenté, V.G., Pelúzio, J.M., Ignácio, M. 2009. Reaction of melon genotypes to the gummy stem blight and the downy mildew. Horticultura Brasileira 27: 160-165.

Santos, G.R., Leão, E.U., Gonçalves, C.G., Cardon, C.H. 2013. Manejo da adubação potássica e da irrigação no progresso de doenças fúngicas e produtividade da melancia. Horticultura Brasileira 31: 36-44.

Santos, G.R., Zambolim, L., Costa, H., Café-Filho, A.C. 2011. Doenças fúngicas, bacterianas e abióticas. In: Santos, G.R., Zambolim, L. (ed). Tecnologias para produção sustentável da melancia no Brasil. Visconde do Rio Branco: Suprema Gráfica e Editora LTDA. p. 95-150.

Savory, E.A., Granke, L.L., Quesada-Ocampo, L.M., Varbanova, M., Hausbeck, M. K., Day, B. 2011. The cucurbit downy mildew pathogen Pseudoperonospora cubensis. Molecular Plant Pathology 12: 217-226.

SEAGRO. 2012. Secretaria da Agricultura, Pecuária e Abastecimento do Tocantins. Produção Agrícola. http://www.seagro.to.gov. $\mathrm{br} /$ <Acesso 20 Jan. 2012>.

Shaner, G., Finney, R.E. 1977. The effects of nitrogen fertilization on the expression of slow mildwing in knox wheat. Phytopathology 67: 1051-1055

Silva, M.A.G., Boaretto, A.E., Fernandes, H.G., Scivittaro, W.B. 2008. Efeito do cloreto de potássio na salinidade de um solo cultivado com pimentão, Capsicum annuum L., em ambiente protegido. Acta Scientiarum Agronomy 23: 10851089.

Simko, I., Piepho, H.P. 2012. The area under the disease progress stairs: Calculation, advantage, and application. Phytopathology 102: 381-389.

Solino, A.D.S., Araújo Neto, S.E.D., Silva, A.N., Ribeiro, A.M.A.D.S. 2012. Severidade da antracnose e qualidade dos frutos de maracujáamarelo tratados com produtos naturais em póscolheita. Revista Brasileira Fruticultura 34(1): 057066.

Viana, T.V.A., Sales, I.G.M., Sousa, V.F., Azevedo, B.M., Furlan, R.A., Costa, S.C. 2007. Produtividade 
do meloeiro fertirrigado com potássio em ambiente protegido. Horticultura Brasileira 25: 460-463.

Zhang, F., Niu, J., Zhang, W., Chen, X., LI, C., Yuan, L., Xie, J. 2010. Potassium nutrition of crops under varied regimes of nitrogen supply. Plant and Soil 335: 21-34.

Zhao, Q., Dong, C., Yang, X., Mei, X., Ran, W., Shen, Q., XU, Y. 2011. Biocontrol of Fusarium wilt disease for Cucumis melo melon using bioorganic fertilizer. Applied Soil Ecology 47(1): 6775. 